
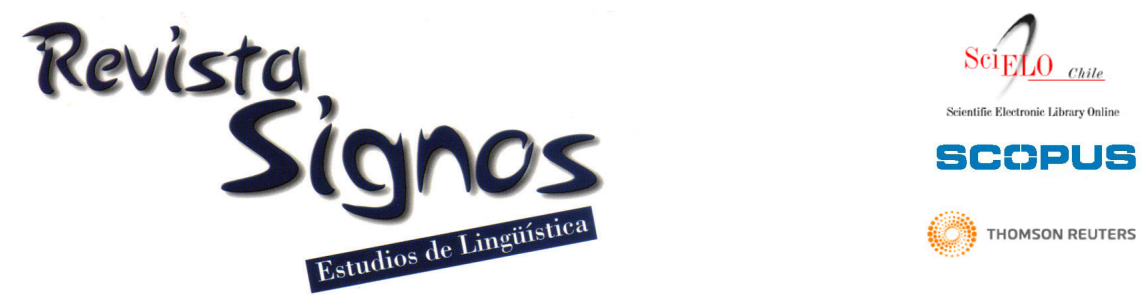

Estudios de Lingius

\title{
The distribution of ser and estar with adjectives: A critical survey
}

\section{La distribución de 'ser' y 'estar' con adjetivos: Una revisión crítica de las propuestas}

\author{
Carolina Holtheuer \\ choltheuer@ciae.uchile.cl \\ Universidad de Chile \\ Chile
}

Recibido: 2-XI-2009 / Aceptado: I5-X-2010

\begin{abstract}
Explaining the distribution of the two Spanish copulas, ser and estar, is still a challenge in current linguistic theory. The aim of the present paper is to provide a critical synthesis and comparison of some of the most influential theoretical proposals that have been put forward to account for the complex distribution of ser and estar with adjectives. First, a general description of the distribution and interpretation of the two Spanish copulas is provided. Then, after showing the inadequacy of the traditional account that views ser and estar as the permanent and temporal copulas respectively, the different semantic, aspectual, semantic-syntactic and pragmatic approaches to explaining their distribution are reviewed. It is observed that most of the recent analyses converge on the following: (i) ser is more flexible than estar in temporal terms, and (ii) ser is independent from the discursive context while estar is always linked to discourse.
\end{abstract}

Key Words: Copulas, syntax, semantics, pragmatics, aspect. 
Resumen: Explicar la distribución de las dos cópulas en español, 'ser' y 'estar', continúa siendo un reto para la teoría lingüística actual. El objetivo de este artículo es proporcionar una síntesis crítica que compare las propuestas teóricas más influyentes que han intentado explicar la compleja distribución de 'ser' y 'estar' con adjetivos. En primer lugar, se ofrece una descripción general de la distribución y la interpretación de las cópulas en español. Luego, después de mostrar las limitaciones de los enfoques tradicionales que consideran a 'ser' y 'estar' como la cópula permanente y temporal respectivamente, se revisan los diferentes enfoques semánticos, aspectuales, sintáctico-semánticos y pragmáticos que explican su distribución. Se observa que la mayoría de las propuestas recientes convergen en los siguientes puntos: i) 'ser' es temporalmente más flexible que 'estar' y (ii) 'ser' es independiente del contexto discursivo mientras que 'estar' permanece siempre ligado al discurso.

Palabras Clave: Cópulas, sintaxis, semántica, pragmática, aspecto.

\section{INTRODUCTION}

The aim of the present paper is to provide a critical synthesis of some of the most influential theoretical proposals that have been advanced so far to account for the alternation of ser and estar with adjectives within the generative framework. It is shown that although none of the analyses is able to deal with the complexity of the behavior of ser and estar, they allow one to understand the basic properties of the two copulas. Even though the issue of what the correct characterization of the copulas must be is far from settled, I show that most analyses converge on the idea that semantic notions cast in terms of temporary/permanent, essential/nonessential properties, cannot be the core distinctions in order to satisfactorily account for the ser and estar alternation. Moreover, in a welcome move, it will be seen that most of the analyses share the idea that pragmatics should be incorporated into any discussion of ser and estar in order to better capture the native intuitions of Spanish speakers. Particularly attention is paid to the functionalist analysis of Clements $(1998,2005)$. The reason is that while Clements (1998) analysis of ser and estar is highly influential, Clements (2005) introduces the use of corpus data that is crucial for providing us with a more accurate view of the actual distribution of the Spanish copulas.

The paper is organized as follows: First, I provide a general description of the distribution and interpretation of the two Spanish copulas. Then, after showing the inadequacy of the traditional account that views ser and estar as the permanent and temporal copulas respectively, I review the different semantic, aspectual, semantic-syntactic and pragmatic approaches to explaining their distribution. It is finally remarked that most of the reviewed analyses converge on the following: (i) ser is more flexible than estar in temporal terms, and (ii) ser is independent from the discursive context while estar is always linked to discourse. Therefore, an important conclusion is that estar establishes a more close relation with the discourse than ser.

\section{General distribution of ser and estar}

Ser and estar are the two copula verbs in Spanish. They have specific uses and even though they overlap in some environments they are not interchangeable:

(I) a. María es/\#está lista. [M. is intelligent]

b. María \#es/está lista. [M. is ready]

c. María es/*está maestra. [M. is a teacher]

d. María es/*está de España. [M. is from Spain]

e. María *es/está de luto. [M. is in mourning]

f. María *es/está comiendo. [M. is eating]

While both ser and estar take adjectival ((la) and (Ib)) and prepositional phrases ((Id) and (Ie)) as complements, only nominal phrases (Ic) appear with ser but not estar, only estar is the auxiliary for the progressive form (If). As (I) shows, ser and estar are present in a diverse range of syntactic constructions. However, it is the 'copula + adjective' construction that is the most interesting to be investigated because while it is relatively easy to predict which verb must be used in locative, nominal and prepositional phrases, explaining the choice of ser and estar in adjectival predicates is rather complex. According to Guijarro-Fuentes and Geeslin (2008) the 'copula + adjective' construction is the most difficult to acquire for second language learners of Spanish. This complexity seems to derive from the fact that choosing the appropriate copula 
is governed by a combination of syntactic, semantic, pragmatic and discursive factors. Guijarro-Fuentes and Geeslin (2008) also notice that the 'copula + adjective' structure is the syntactic frame that allows the greatest co-occurrence of ser and estar. Therefore, the 'copula + adjective' construction is, in theory, the construction that would better inform learners about the different semantic, aspectual, pragmatic and discursive properties of ser and estar.

While both ser and estar take adjectival (( la) and (Ib)) and prepositional phrases ((Id) and (Ie)) as complements, only nominal phrases (Ic) appear with ser but not estar, only estar is the auxiliary for the progressive form (If). As (I) shows, ser and estar are present in a diverse range of syntactic constructions. However, it is the 'copula + adjective' construction that is the most interesting to be investigated because while it is relatively easy to predict which verb must be used in locative, nominal and prepositional phrases, explaining the choice of ser and estar in adjectival predicates is rather complex. According to Guijarro-Fuentes and Geeslin (2008) the 'copula + adjective' construction is the most difficult to acquire for second language learners of Spanish. This complexity seems to derive from the fact that choosing the appropriate copula is governed by a combination of syntactic, semantic, pragmatic and discursive factors. Guijarro-Fuentes and Geeslin (2008) also notice that the 'copula + adjective' structure is the syntactic frame that allows the greatest co-occurrence of ser and estar. Therefore, the 'copula + adjective' construction is, in theory, the construction that would better inform learners about the different semantic, aspectual, pragmatic and discursive properties of ser and estar.

\section{Ser and estar with adjectives}

Although both copulas take adjective complements and many adjectives are compatible with both ser and estar, not all adjectives are compatible with both copulas. The sentences in (2) illustrate this point.

(2) a. María es/está bonita/alegre/callada. [M. is pretty/happy/quiet]

b. Juan *es/está peinado/cansado. []. is combed/ tired]

c. Juan es/?está inteligente/sincero. [J. is intelligent/sincere]

In Spanish, certain adjectives, as exemplified in (2a), can appear with both copulas and most participial adjectives can go with estar, but are incompatible with copula ser as illustrated in (2b). Also certain adjectives are not usually acceptable with copula estar as exemplified in (2c). In order to describe adjective compatibility with ser and estar, Luján (198I) divides adjectives in three types: those that can only appear with ser (e.g. injusto [unfair]); those that can only appear with estar (e.g. lleno [full]); and those that appear with both ser and estar (e.g. alto [tall]).

Apart from the distributional differences, the use of one or the other copula is generally associated with differences in interpretation, some more pronounced than others. Some adjectives have different lexical meanings depending on whether they appear with ser or with estar (3a). Similarly, some adjectives yield a different interpretation of the predicate depending on whether ser or estar is used (3b), although they keep the same lexical meaning.

(3) a. Juan es/está vivo. [J. is intelligent (ser)/ is alive (estar)]

b. Juan es/está alto. [J. is normally tall (ser)/ is tall right now (estar)]

In sum, many adjectives are compatible with both copulas but their use is dictated by different syntactic, semantic and pragmatic factors. Next, I present several theoretical proposals that have been put forward for explaining the complex distribution of ser and estar.

\section{Accounting for distributional differences of ser and estar}

There are innumerable theoretical accounts that attempt to explain the distribution of ser and estar with adjectives but most of the analyses do not provide a principled explanation for selecting the 'right' copula. In this section I review some of the most influential accounts of ser and estar: Luján (1981), Clements (1988), Diesing (1990, 1992), Kratzer (1989, 1995), Schmitt (1992, 2005), Schmitt and Miller (2007), Maienborn $(2003,2005)$ and Arche (2007). I begin by introducing very briefly how the ser and estar distinction has been traditionally approached. It is worth noticing that even though most linguists have recently argued against the traditional division of ser and estar, this is still the prevalent account that is offered to second language learners of Spanish. 


\section{I. Traditional approaches: Semantic notions are not enough}

In general, traditional approaches have accounted for the ser/estar opposition in terms of semantic notions. Bello (I95I) treats ser as expressing a permanent quality and estar as expressing a transitory quality of the subject. In (4) below, Juan is commonly described as having the permanent quality of being a tall person with ser but having the transitory quality of being tall if estar is used.

\section{(4) Juan es/está alto. [J. is (ser/estar) tall]}

Similarly, Gili Gaya (1955) argues that ser is used for inherent situations and estar for circumstantial and contingent states. More lately, Vañó-Cerdá (1982) presents the distinction in terms of intrinsic and objective quality for ser versus extrinsic and subjective quality for estar. Although these explanations account for some cases, none of them captures a straightforward generalization. Counterexamples to these semantic notions, such as those in (5) are abundant. Note that the adjectives that mean 'temporariness' never take estar (Delbecque, 1997).

(5) La locura de Juan es/*está temporal. [Juan's craziness is temporary]

Also, if 'permanency' versus 'temporariness' of a property were the distinction at work when selecting the copula, the sequence ser joven [being young] in (6) should always be constructed with estar. Notice that in (6), the property of being young cannot last longer than the property of being alive. However, alive is used with estar and young is used with ser.

(6) Juan está vivo... ¡Y es joven! [Juan is alive... And he is young]

Many adjectival predicates do not necessarily refer to permanent properties. Arche (2007) observes that only predicates denoting properties related to the origin of individuals such as 'Eskimo' and 'Gypsy', can be conceived as more or less permanent. Other adjectives such as 'blond' or 'young', are properties that may only apply for a limited period of time and therefore are not necessarily permanent properties. Therefore, it is not clear that temporal notions are what dictate the distinction between ser and estar.

\subsection{Luján's (I98I) semanticlaspectual analysis}

Luján's (198I) analysis of ser and estar dates back to the eighties but the aspectual component of her proposal has been very influential in the works of several researchers (Fernández-Leborans, 1999; Porroche, 1990; Camacho, 1997; Schmitt, 1992, 2005; Marín-Gálvez, 200 I; Roby, 2007).

Luján's semantic (198I) analysis is interesting in three respects. The first relates to the difference of the intrinsic semantic features of the copulas. For Luján, ser is <+COP>, <+/- Stative $>$ and <Perfective $>$ while estar is $<+C O P\rangle,<+$ Stative $>$ and <+Perfective>. Therefore both ser and estar are copulas, but, while ser is both stative and nonstative, estar is always stative. The copulas also differ in their perfective nature with ser being always imperfective and estar always perfective. The second point of Luján's analysis is that adjectives are divided in three groups based on whether they occur with ser or with estar or with both copulas: Group I contains the adjectives that typically go with ser, group 2 includes adjectives that could only go with estar and group 3 includes adjectives that appear with either copula. She assigns <+/-perfectivity> features to these adjectives, showing that adjectives can also be specified for aspectual properties. Thus, adjectives that typically go with ser are <-Perfective>, adjectives that only go with estar are <+ Perfective> and adjectives that are acceptable with both copulas are neutral in terms of perfectivity. Since Luján (198I) claims that ser is <-Perfective> and estar is <+Perfective> and because adjectives can be differentiated based on whether they carry a perfectivity feature as well, her analysis allows us to account for the cases of incompatibility between copula and adjectives such as those in (7).

(7) a. Juan *es/está peinado/cansado. [J. is combed/ tired]

b. Juan es/?está inteligente/sincero. []. is intelligent/sincere]

Since es (ser) in (7a) is <-Perfective> and adjectives cansado and peinado are <+Perfective>, there is a semantic/aspectual clash. A similar clash results in (7b) in which the <+Perfective> copula estar is incompatible with the <-Perfective> adjectives inteligente and sincero. Therefore Luján's (I98I) analysis is superior to traditional accounts in that 
it eliminates the need for explaining ser and estar distribution based on vague semantic notions like temporariness, contingency, change etc. that leave unexplained numerous cases of ser and estar. Her proposal accounts for a wider range of the ser and estar opposition phenomenon. However, there is a problem of descriptive adequacy regarding her proposal that copulas and adjectives are marked for the feature <+/-Perfective>. It is not clear that estar and estar-type adjectives are specified for a $<+$ Perfective> feature since they do not necessarily presuppose an ending point. Perfectivity is not about an ending point but rather about including an ending point when there is one. Traditionally, a perfective state is defined as entailing an ending point (Leonetti, 1994). Notice that in sentences in (8) below that are constructed with estar there is nothing telling us that the state of being pretty or tired is going to end.

\section{(8) a. María está bonita/cansada. [María is (estar) pretty/tired]}

The third component of Luján's (198I) analysis is highly relevant for understanding the complex relationship between the copulas. She argues that ser and estar stand in an entailment relationship, in which estar is a subset of ser. She illustrates this point by assigning truth-values to the sentences in (9).
a. Luisa está gorda/bonita/alegre porque es gorda/bonita/alegre. (True)
[Luisa is fat/pretty/happy because she is fat/ pretty/happy]
b. Luisa es gorda/bonita/alegre porque está gorda/bonita/alegre. (False)
[Luisa is fat/pretty/happy because she is fat/ pretty/happy]

Her analysis accounts for the difference in interpretation of $(\mathrm{IOa})$ and $(\mathrm{IOb})$ below:
(I0) a. María es bonita. [M. is pretty]
b. María está bonita. [M. is pretty (right now)]

Luján (I98I) claims that sentence (IOb) entails sentence $(\mathrm{IOa})$ but the opposite, that $(\mathrm{IOa})$ entails $(\mathrm{IOb})$ is not possible. In other words, estar entails ser but ser does not entail estar. It is worth noticing, however, that this relationship between ser and estar is only valid when both sentences with ser and estar refer to the same exact slice of time. As in any entailment relation, a necessary condition is that both sentences ( $\mathrm{IOa}$ ) and $(\mathrm{IOb})$ must be true in the real world. In other words, María has to be a pretty person and also look pretty at the speech moment. It is possible (and also very frequent) to use ser and estar, not as partial synonyms, as the entailment relation suggests, but as opposite terms in which the use of estar implicates the negation of ser. For example, someone can say (II) below in order to implicate that María is not generally a pretty person and also use (I2) in which the ser property is negated. Notice however, that negating the ser property does not contradict the idea that María estar pretty.

(II) María está bonita. [M. is pretty (right now)]

(12) María está bonita pero no es bonita. [M. is (estar) pretty but is (ser) not pretty]

Therefore, although informative, the notion that estar + adjective can be a subset of ser + adjective is not an absolute generalization and therefore it cannot be an entailment. We should keep in mind that the partial synonymy relation that sometimes holds between ser and estar is not always operative and importantly, that it ceases to hold depending on pragmatic or extra grammatical factors.

In sum, the semantic-aspectual analysis proposed by Luján (I98I) offers a more thorough account of the differences in distribution and interpretation of the Spanish copulas than previous traditional analyses. However, there are still shortcomings in that it cannot explain why ser and estar behave as partial synonyms in some contexts but have opposite meanings in other contexts. Next I review other accounts that attempt to explain this puzzle by incorporating pragmatic factors. But before, I review an account that is still very popular for explaining the opposition between ser and estar: the Stage/ Individual Level proposal.

\subsection{The individual level and stage level dichotomy}

Two influential analyses of copular constructions that have been used to explain the opposition of ser and estar in Spanish are the ones proposed by Diesing (1990, 1992) and Kratzer (1989, 1995). Before considering the details of their proposals we need to refer very briefly to the Individual Level (IL) and Stage Level (SL) semantic distinction between predicates put forward by Carlson (1977). This is important since both Diesing's (1992) and Kratzer's (1995) analyses attempt to give a syntactic/semantic account of the different interpretations that these predicates receive. 
Carlson (1977) draws a distinction between two kinds of predicates: Stage-Level Predicates (hence SLPs) that characterize properties of stages and Individual-Level Predicates (hence ILPs) that characterize properties of individuals. In Carlson's terms (1977: I55-I28), a stage is a 'space-time slice' of an individual while individuals are "a series of stages... of the same thing". Carlson (1977) argues that this distinction is based on the acceptability of certain predicates as complements of perception verbs. He observed that only predicates that express transitory or accidental qualities (SLPs) but not those that express permanent or essential qualities (ILPs) are acceptable as complements of perception verbs, as in (I3).
a. *John saw Jane intelligent.
b. John saw Jane tired.

The predicate 'intelligent' in Carlson's (1977) terminology is an ILP because 'intelligent' is a permanent property that applies to individuals, while the predicate 'tired' is a SLP because it denotes a transitory property that applies to stages of an individual. He also observes that bare plural subjects with ILPs cannot have an existential reading while SPLs admit both generic and existential readings:
a. Dogs are mammals. (generic only)
b. Dogs are in the park. (generic and existential)

In order to account for these facts and for the interpretation of other indefinites, Diesing (1992) and Kratzer (1995) propose that the semantic IL/ SL distinction follows from differences in argument structure. Specifically, Kratzer (1995) argues that Diesing's (1992) proposal that subjects of ILPs and SLPs may be in different syntactic positions is a consequence of a difference in argument structure: SLPs have an extra argument position for events or spatio-temporal locations while ILPs do not. They both assume Heim's (1982) proposal that i) indefinites are open formulas that contain a free variable that undergoes an operation of existential closure and ii) that sentences are mapped to a tripartite Logical Form that consists of a quantifier, a restrictive clause and a nuclear scope. For Diesing (1992) material from the VP is mapped into the nuclear scope where the variable undergoes existential closure while the material from the IP is mapped into a restrictive clause and, if there is not an overt operator present, a generic null operator can be inserted giving rise to the only possible reading: generic. Since the subject of an SLP is generated inside the VP, it can either raise to Spec IP or stay in the VP, and therefore can receive both interpretations. In ILPs the subject is generated in IP and cannot reconstruct to VP. Therefore it only receives a generic reading. For Kratzer (1995) SLPs have a Davidsonian argument that locates in space and time the property or event that is predicated. This argument has the form of a variable that can be bound by an adverbial or by existential closure. The presence of this extra argument in SLPs but not in ILPs would explain why SLPs but not ILPs can appear with certain kinds of adverbials:

(I5) a. *When Mary knows French, she knows it well.

b. When a Moroccan knows French, she knows it well.

c.When Mary speaks French, she speaks it well.

(I5a) is not acceptable because 'When' does not have anything to quantify over (there is not a Davidsonian argument to bind since 'know' is an IL head). (I5b) on the other hand is acceptable because 'When' binds the indefinite 'a Moroccan' that is also a variable. (I5c) is also acceptable since the predicate headed by 'speak' is SL and has a Davidsonian argument. However, a problem for the syntactic account is that in the same way as SLPs can have IL readings, in (I6), typical ILPs can be assigned $S L$ readings, in (I7) (Manninen, 200I):

(I6) a. John smoked grass.

b. John drank whisky.

(I7) John was intelligent. = John was (always and without exception) intelligent. $=$ John behaved in a really stupid way yesterday, but today he was quite intelligent.

A case like (I7) cannot be explained easily by using Kratzer's (1995) analysis, unless event arguments can be added when needed, and much less by making event arguments a lexical property of the inflectional head (the copula 'was'). Diesing (1992) suggests that the SL/IL distinction can be applied to Spanish, namely that ser and estar correlate with IL and SL predicates respectively. Her analysis accounts for the Spanish copulas in the following way: The subject of ser is generated in IP. Since it cannot reconstruct to VP, it can only receive a generic reading. The subject of estar is generated inside the 
VP.Therefore, it can either raise to IP and receive a generic interpretation or stay in the VP and receive an existential interpretation. This yields the pattern in (18).

a. Un bombero es altruista. [A fireman is altruistic]

b. Un bombero está disponible. [A fireman is available]

The indefinite subject in (I8a) with copula ser can only receive a generic reading while the indefinite in (18b) with estar can be ambiguous between an existential and generic reading. However, Schmitt (1992) provides evidence against considering ser and estar as the IL and the SL copulas, respectively:

a. Sempre que María é rude/cruel/gentil, ela é mesmo rude/cruel. [When (ever) María is (ser) rude/cruel, gentle, she is really rude/cruel]

b. Sempre que Clark Kent é Superman, a cidade está segura. [When (ever) Clark Kent is (ser) Superman, the city is safe]

Schmitt (1992) observes that, if we follow Kratzer's analysis, both sentences (19a) and (19b) need to project a Davidsonian argument. The problem is that we cannot maintain the generalization that ser + predicate is an ILP and estar + predicate is a SLP because only SLPs are supposed to project a Davidsonian argument according to her analysis. However, both (19a) and (19b) are acceptable although the verb used is ser. She points out that while estar behaves as SL with respect to the Davidsonian argument, ser does not behave as IL in every case. She shows that ser allows an existential interpretation of bare plurals in certain contexts (in Portuguese):

$$
\begin{aligned}
& \text { a. María está sendo cruel. [María is being } \\
& \text { cruel] } \\
& \text { b. Há mulheres sendo cruéis. [There are } \\
& \text { women being cruel] }
\end{aligned}
$$

If the bare plural in (20b) receives an existential interpretation, why is it that the copula used is ser and not estar? As Schmitt (1992) shows, a syntactic account that correlates IL and SL predicates with copulas ser and estar is inadequate to explain the distribution facts of the Spanish and Portuguese copulas.
Maienborn (2005) is also very critical of the IL/SL implementation for explaining ser and estar. In a similar vein, she cites the example in (2I) (previously provided by Querido, 1976), in which a botanist who had just discovered a tree from a previously unknown species in the Amazonian jungle needs to decide between ser and estar in order to describe the yellow color of the leaves.

(2I) Las hojas de este árbol son/están amarillas.

[The leaves of this tree are yellow]

The botanist does not know whether the leaves are always yellow or change colors. Therefore, he/ she may use estar with adjective amarillas 'yellow' since this choice does not exclude the possibility that the leaves may change colors. In other words, the botanist may use estar because it does not corroborate nor contradicts that the leaves are generally or temporarily yellow in the context. Maienborn (2005) convincingly argues that the serl estar alternation cannot be reduced to conceptual oppositions such as 'temporary vs. permanent' and concludes that it is the speaker's perspective on a predication in a particular discursive context what dictates the use of ser and estar. Therefore her proposal suggests that if we are to understand the behavior of ser and estar, we need to investigate their pragmatic properties.

\subsection{Integrating pragmatics: Clements (1988, 2005)}

Clements (1988) is one of the first researchers to suggest that pragmatic factors are involved when choosing between ser and estar in adjectival constructions. He proposes an analysis that takes into account the semantics of each copula; and importantly, the pragmatic factors regarding the sentence subject (called the referent (R)), the point of view of the Speaker (S), and the understood beliefs we have about the nature of states and characteristics denoted by adjectives. The first pragmatic factor relates to the presence or absence of the feature termed Nexus that establishes a connection to another situation or state. Nexus is defined as the position of the subject referent in space or to a prior or assumed state or situation of the referent. Ser and estar differ in their specifications for Nexus. While ser is <-Nexus> (its semantics does not presuppose any type of connection to either location or a previous state of R), estar is $<+$ Nexus $>$ because it presupposes it. 
The second pragmatic factor in Clements's (1988) analysis concerns the point of view of the speaker. The speaker classifies the referent according either to a class norm (a norm valid for a group) or to an individual norm. For classifying a referent as a class norm, the speaker will use ser such as in (22a) but if the speaker classifies a referent according to an individual norm he will use estar (22b).

a. Para su edad Pepe es bien alto. [For his age, Pepe is (ser) quite tall]

b. Pepe ¡Qué alto estás! [Pepe, how tall you are (estar)]

Clements (1988) proposes a third and final pragmatic factor in relation to whether adjectives are specified for a resultative feature. He argues that if we only consider the distinction between the copulas and the view of the speaker we could conclude that any copula could go in any copulative sentence. This is certainly not true. In order to explain this variation, Clements (1988) argues that there are certain adjectives that are specified for a resultative feature. This resultative feature allows the speaker to select either a class norm or an individual norm. For example in (23) below, the speaker overrides the <+Nexus> interpretation when using adjective ancho 'wide', which is <+ Resultative>:
a. La carretera es ancha ahora. [The road is (ser) wide now] <- Nexus>
b. ¡Qué ancha está la carretera! [How wide the road is (estar)] <+ Nexus>

However, Clements (1988) takes more factors into account for explaining the distribution of ser and estar. The ancho-type adjectives imply a contrast to a prior situation but there are other adjectives that denote only a resultative state without any implicit comparison. These adjectives are marked $<+$ Resultative $>$ and they are only compatible with estar $<+$ Nexus $>$. These are the adjectives (called participial adjectives) that give rise to ungrammatical sentences if ser is used. However, there are exceptions, as the author acknowledges. These are $<+$ Resultative $>$ adjectives that are compatible with both ser <-Nexus> and estar <+Nexus>:

$$
\begin{aligned}
& \text { Pedro es/está contento/callado [P. is (ser/ } \\
& \text { estar) happy/quiet] }
\end{aligned}
$$

Therefore, even though Clements (1988) was a good description of the 'copula + adjective' construction facts, and one of the first to incorporate pragmatic factors, it did not satisfactorily account for the alternation of ser and estar in frequent expressions such as those in (24) above. Later on, however, Clements (2005) manages to account for these expressions by including the notion of directionality in the classification of adjective types. By this and the inclusion of the notion of animacy of the subject his new analysis allows for better predictability of copula compatibility with adjectives. Importantly, like many other linguists (Fernández-Leborans, 1999; Porroche, 1990; Camacho, 1997; Luján, I981; Schmitt, 1992, 1996, 2005), Clements (2005) adopts the notion of [aspect] and distinguishes between the two copulas in semantic terms by arguing that estar but not ser carries the feature [aspect]. Following previous work on adjective types (Clements, 1988) he notes that the ILP/SLP distinction makes the right predictions for some but not all adjectives. In order to account for the correct distribution of the copulas with adjectives Clements (2005) follows Vendler (1967) classification of dynamic situations and classifies adjectives as referring to different state types. By also incorporating the notion of time stability, Clements (2005) analysis makes the following correct predictions: (i) Since ser is unmarked for the feature [aspect], it will mostly appear with adjectives that have no underlying dynamic situation such as mortal and intelligent, (ii) Since estar is marked for [aspect], it will mostly appear with adjectives that have an underlying event (telic and less stable in time) such as standing and baptized; and (iii) adjectives that have underlying processes will appear with both ser and estar such as tall and young.

Unlike generativist accounts, a strong point of Clements' (2005) analysis is that he uses corpus data in order to test his predictions. For example, based on the analysis of the frequencies from CREA (Corpus de Referencia del Español Actual of the Real Academia Española) and Alameda and Cueto (1995) he shows that ser is the default copula for most adjectives. He explains that this behavior is expected since ser as opposed to estar is semantically underspecified for [aspect]. As a result, forms of ser are overall much more frequent than forms of estar in the corpus.

\subsection{Maienborn's $(2003,2005)$ discourse account}

Unlike the analysis of Clements $(1988,2005)$ in which semantics plays a big role in distinguishing 
between the two copulas, Maienborn (2003, 2005) proposes a discourse-based account in which the difference between ser and estar lies exclusively in how they relate to the discourse. While estar predications are linked to a specific discourse situation, ser predications are neutral or not specifically linked to the discourse. In her view, ser and estar are semantically identical but differ in presupposing a link to a specific discourse situation. In other words, the use of estar restricts the domain in which a property holds to a specific discourse situation while no restriction arises when ser is used. As support for her claim that the difference between ser and estar cannot lie in the grammar, she performs standard eventuality tests that show the inadequacies of explaining the ser and estar alternation based on a Davidsonian approach. Remember that Davidsonian arguments are spatiotemporal entities that have the function to locate in space and time the property or event that is predicated. The SL/IL distinction assumes that estar but not ser introduces an eventuality argument that allows it to be located in space or time.

Maienborn (2005) carried out the following tests in order to test the assumption predicted by the IL/ $\mathrm{SL}$ implementation that estar but not ser projects a Davidsonian argument:

i) Combining with locative modifiers:

a. *El juguete es amarillo debajo del árbol. [The toy is yellow under the tree]

b. Pablo estaba durmiendo debajo del árbol. [Pablo was sleeping under the tree]

One prediction of the SL/IL distinction is that estar but not ser combines with locative modifiers. However, Maienborn (2005: 163) notes this is not the case, as illustrated in (26) below.

a. *La camisa está mojada sobre la silla.

[The shirt is wet on the chair]

b. *El champán está tibio en la sala.

[The champagne is warm in the living room]

She adds that if the estar predicate withAP introduced an event argument, sentences in (26) should be acceptable. Thus, according to this eventuality test, ser and estar do not behave differently suggesting that they do not differ in terms of eventuality arguments. In other words, ser and estar are not grammatically different with respect to their ability to co-occur with locative modifiers. Both ser and estar are unacceptable when co-occurring with event-related locatives.

ii) Combining with manner adverbials: Maienborn (2005) observes that regular eventuality expressions combine with manner modifiers:

(27) a. Luis esperaba solo/sin Carol/ pacientemente/ ansiosamente a Dolores. [Luis waited alone/without Carol/ patiently/ anxiously for Dolores]

However, she cites the following examples in which both ser and estar predications are unacceptable with manner adverbials:

(28) a. *Las manzanas eran/estaban dulces sabrosamente.

[The apples were sweet deliciously]

b.*Doloresera/estabaguapa elegantemente. [Dolores was pretty elegantly]

iii) Combining with Infinitival complements of perception verbs: Perception verbs take eventuality expressions as infinitival complements in (29) but neither ser nor estar display this behavior in (30):

(29) Yo ví a Carol esperar frente a la casa. [I saw Carol wait in front of the house]

(30) ??Yo vi a Carol ser/estar guapa. [I saw Carol be pretty]

She notices, following Schmitt (1992), that when the context supports an agentive reinterpretation, the sentence improves:

(3I) Yo ví a María ser cruel (con los gatos). [I saw M. be (ser) cruel (with the cats)]

Maienborn (2005) argues that if ser and estar (especially estar) did indeed introduce a Davidsonian argument, no additional contextual support would be needed to license the use of them. In addition, she suggests that given that eventive coercion is available for both ser and estar, estar predications are not more 'eventive' than ser predications. 
Maienborn (2005) is also against accounting for the difference between ser and estar in terms of aspect. She observes that there is an aspectual component to her treatment of ser and estar but clarifies that

"I take (any) aspect to be the source of the topic situation, which, for independent reasons, turns out to be a suitable antecedent for estar's specificity presupposition" (Maienborn, 2005: I3).

In sum, she concludes that ser and estar have the same grammatical structure, and the same semantics, but differ only in pragmatic terms.

\subsection{Schmitt's (1992, 1996, 2005) aspectual account}

Like other linguists (Fernández-Leborans, 1999; Porroche, 1990; Camacho, 1997; Luján, 198I), Schmitt $(1992,1996,2005)$ has argued that the difference between ser and estar lies in their aspectual properties. For Schmitt (1992) the two copulas are semantically distinct: while ser is underspecified for aspect, estar is specified for aspectual properties. Ser is interpreted as a state that does not contribute any semantic content. Hence, it does not allow temporal interpretations unless aspectual operators such as ahora 'now' are added. For example consider the pair in (32):

(32) a. Mariana es alta. [Mariana is (ser) tall] b. Mariana es alta ahora. [Mariana is (ser) tall now]

In (32a), the tallness of Mariana is a property that does not hold at any specific time. The tallness of Mariana in (32b), on the other hand, is temporally anchored (at speech time), as a result of adding adverbial 'now'. Interestingly, the sentence in (32b) is equivalent in meaning to that in (33) below constructed with estar. This equivalency between ser + 'now' and estar derives from the fact that estar predications are always temporally anchored.

$$
\text { Mariana está alta. [Mariana is (estar) tall] }
$$

An important point of Schmitt's (1996) work is that she proposes that Kratzer's (1995) test (that only SLPs can be modified by temporal or frequency adverbs) be reanalyzed as a test for determining if a predicate has the appropriate aspectual properties. In order to support her claim that the adverbial 'when(ever)' selects for aspectual properties, Schmitt (1996) provides the following example (in Portuguese):
(34) a. *Sempre que João comeu a/uma sobremesa, ele ficou doente. [When(ever) João ate (perfective) the/a dessert, he got (perfective) sick]

b. Sempre que João comía a/uma sobremesa, ele ficava doente.

[When(ever) João ate (imperfective) the/a dessert, he got (imperfect) sick]

In (34a) the verb eat cannot be perfective because the use of 'when(ever)' forces the clause to be interpreted as distributed over time. Notice that the type of predicate $(\mathrm{SL})$ is entirely irrelevant in the presence of the adverbial. What is crucial in this case is that the same sentence is acceptable if the aspect is imperfective. By arguing that the adverb when(ever) is sensitive to the aspect of the clause it interacts with, Schmitt's (1996) analysis can easily account for sentence (35) that is problematic for Kratzer's (1995) syntactic account:

(35) Siempre que María es cruel, ella es muy cruel. [When(ever) María is rude, she is really cruel]

In (35), copula ser receives an Act be interpretation (Partee, 1977) and the clause receives an aspectual reading. Adverbial siempre forces the whole ser + predicate to be interpreted as anchored in time. Notice that by claiming that ser is underspecified for aspect, Schmitt (1996) accounts for the possibility of ser receiving a SL interpretation. Thus it follows naturally that the interpretation of ser will depend on the type of predicate it takes. This is an elegant solution to the problem of how to explain the different interpretations that ser receives without having to stipulate two lexical entries for ser. Estar, on the other hand, will always receive a SL interpretation since its aspectual nature makes it temporally anchored.

Recently, Schmitt and Miller (2007) incorporated pragmatics into Schmitt's (1992) original analyses in the following way:

“...since ser + predicate does not involve any reference to some specific interval, then the use of ser brings about the implication that the property holds independent of time" (Schmitt \& Miller, 2007:14).

This last proposition is important because it makes two predictions. First, while estar predicates are always interpreted as STATES (and therefore always receive SL readings), ser is flexible in terms of its event type properties. And second, because 
estar is a state that holds at time $t$, it gives rise to an implicature of temporariness. As a result, it is possible to account for the non-infrequent cases in which Spanish speakers use ser + predicates to describe both inherent/permanent and noninherent/non-permanent properties. For example, imagine a context (example slightly modified from Schmitt \& Miller, 2007) in which there are two cats, a yellow cat that was born fat and a black cat that was born skinny. Imagine further that they grow, and that as adults they eat some magic beans. As a result, the fat yellow cat remains fat but turns green for three minutes but the black skinny cat remains black but turns fat for three minutes. Importantly, we are aware that the magic beans only work for three minutes and that the cats will return to their original fat and skinny states once that time has passed. But crucially, we are interested in using ser or estar at the time when both cats, the black and the yellow, are equally fat. Thus imagine that we are at the exact moment when the transformation has just taken place. Now, if ser is the inherent/ permanent copula while estar is the non-inherent/ non-permanent copula the prediction is that Spanish speakers would answer 'the yellow one' to the question 'Which cat ser fat' but would answer 'the black one' to the question 'Which cat estar fat'. However, this is not necessarily so. There is certain flexibility in the answers. Notice that since both cats are fat at the time the question is posed, speakers can use either ser or estar to describe both cats. The following sentences (with either ser or estar) are adequate descriptions according to the context:

a. El gato negro es/está gordo.

[The black cat is (ser/estar) fat]

b. El gato amarillo es/está gordo.

The yellow cat is (ser/estar) fat]

Notice that in (36) both ser and estar can be used for describing both, the temporarily fat cat and the permanently fat cat. Hence, the notions of change/ no change, temporary/permanent, inherent/noninherent properties that most traditional accounts embrace, including the popular SL/IL account, do not seem relevant for explaining the choice between ser and estar in this context.

\subsection{Arche's (2007) new interpretation of the ILI SL Dichotomy}

For Arche (2007), the semantic characterization of ser and estar corresponds to the IL/SL distinction. Ser predications refer to properties that apply to an individual while estar predications refer to properties that apply to an individual on a particular occasion and that are linked to external reasons. For example, in sentence (37) below, when using ser the speaker claims that Pablo is handsome, dark-skinned, or a funny person but when using estar the speaker conveys that Pablo has (at that particular occasion) all the properties by external reasons such as, he is wearing a nice suit, got tanned or is in a good mood.

Pablo es/está guapo/moreno/gracioso. [P. is (ser/estar) handsome/dark-skinned/funny]

Very generally, Arche (2007) argues that the difference between the lexical exponents of the IL and SL predicates, ser and estar, cannot be explained by adducing temporal, outer aspect and or inner aspect distinctions. Hence, her proposal departs radically from previous accounts of ser and estar that base their explanation on aspectual differences between the copulas. For her, Inner Aspect (Verkuyl, 1989), also known as 'Aktionsart' or 'Situation Aspect' (Smith, 1997) refers to the internal properties of events in sentences such as duration, culmination and delimitation.Arche (2007) proposes that eventualities are not lexically specified as states or achievements but rather receive their aspectual interpretation from their syntactic structure. The aspectual properties of eventualities derive from whether AspQMax (quantity) is projected into the syntax: the presence of this functional node makes an event be interpreted as telic while the absence of it results in an atelic interpretation. Hence, inner aspectual properties can be recast in terms of quantificational properties.

In contrast, Outer Aspect differs from Inner Aspect in that it does not refer to the internal structure of events but to the number of instances an eventuality takes place and to whether the eventuality is presented as ongoing, over or before its beginning (e.g. aspectual viewpoints like progressive, perfective and imperfective). Outer Aspect is an ordering predicate that selects the interval the sentence makes an assertion about and relates it to the total interval of time the event takes place. Arche (2007) calls the interval the speaker refers to as the Topic Time (TT). TT is different from the total interval that the event takes place, also known as Eventuality Time (ET). In sum, Aspect establishes the relation between TT and ET.

A crucial point of Arche's (2007) analysis is her treatment of ser predicates. She notes that most previous literature on the topic view IL predicates 
as belonging to the group of states. This is that IL (ser) predicates are eventualities that just 'hold' and are inherently durative. However, she shows that not all IL predicates behave as states. Some AP predicates, like cruel behave as events in some contexts. In order to show this difference, Arche (2007) carries out a set of aspectual tests such as that for the progressive form in (38) and shows that whereas activities and accomplishments are grammatical in the progressive form, states are not. Notice that some IL predicates like Eskimo and blond are ungrammatical in the progressive while IL predicate cruel is fine.
a. *Juan estaba siendo esquimal. [Juan was being an Eskimo]
b. *Juan estaba siendo rubio. [Juan was being blond]
c. Juan estaba siendo muy cruel con Pedro. [Juan was being very cruel with Pedro]

Therefore, according to these tests, the three predicates with ser ('Eskimo', 'blond' and 'cruel') do not seem to correspond to the same class of predicates. 'Ser Eskimo', and 'ser blond' behave as states (e.g. they are ungrammatical in the progressive form) while ser cruel behaves as an event. In order to have a more concrete sense of how Arche's (2007) proposal bears on the theoretical treatment of ser and estar, I next review how it differs from previous accounts.

3.7.I. Differences with previous proposals. Difference with Kratzer's (1995) analysis

Remember that Kratzer's (1995) temporal interpretation depends on argument structure. While SL predicates have an external argument that allows them to be located in space and time, IL predicates lack this spatiotemporal variable. For Arche (2007), both IL and SL predicates have a spatiotemporal variable. This variable is bound by an over-occasions-quantifier that can be present with any kind of predicate if an appropriate context is built up. Thus, temporal interpretation depends on the content of the Topic Time (TT) with respect to the Reference Time (RT). For example:

(39) Harry y María llegaron a los EEUU. Harry estaba enfermo y pidió ayuda para recoger la maleta. [Harry and Maria arrived to the EUA. Harry was (estar) sick and asked for help for picking up the suitcase]
(40) Harry y María llegaron a los EEUU. Harry era de California, por lo que no tuvo que pasar por la aduana. [Harry and Maria arrived to the EUA. Harry was (ser) from California, so he did not have to go through customs]

For Arche (2007), Tense takes the TT interval and orders it with respect to the interval taken as reference. In both examples above Topic Time equals to the time of arrival. Notice, however that both ser and estar are used.Therefore the temporal interpretations of (39) and (40) depend on the content of TT and not on whether ser or estar are used. Similarly, she reasons that the IL/SL distinction cannot be related to the realm of tense. If tense orders TT with respect to a Reference Time (time of arrival in (39) and (40) above), and ser and estar (or IL/SL) predicates were to be distinguished in temporal terms, we would expect to find a difference between the use of ser and estar. However, these examples reveal that any difference between ser and estar are not relevant.

\subsubsection{Difference with Maienborn}

While for Maienborn (2005), ser and estar have identical semantic properties, for Arche (2007), the serlestar contrast is rooted in the lexicon. Estar conveys the linking to an external situation lexically and "refers to a circumstance in which an individual is" (Arche, 2007:25I). Since ser is more vacuous than estar in a lexical sense while ser does not impact the adjective, estar does it by associating the property to a concrete situation.

\subsubsection{Difference with aspectual proposals}

Arche (2007) observes that Luján (198I), Schmitt (1992, 1996, 2005) and Fernández-Leborans (1999) make use of aspectual notions to account for the difference between ser and estar. Luján (I98I) establishes a difference in terms of delimited and undelimited predicates, Schmitt (1992, 1996, 2005) in terms of specification or underspecification with respect to aspect and Fernández-Leborans (I999) in terms of possessing or not possessing internal temporal structure. However, for Arche (2007), aspect is not the relevant notion for deciding between ser and estar. She argues that ser-clauses differ with respect to Inner Aspect. IL predicates are not all stative. When Inner Aspect is taken into account there are stative and dynamic IL predicates. The dynamic and active properties observed 
in certain IL predicates such as cruel, kind and mean are due to the syntactic contribution of the complement the copula appears with. Specifically, dynamicity results from the contribution of the relational complement of the adjective (cruel to Mary) to the whole VP. The preposition (whose appearance is optional) is what provides aspectual content to the VP, triggering a shift from a stative ser cruel to activity ser cruel con María. Ser predicates with adjectives such as cruel, mean and kind can have both a stative and active reading. She reasons that since both ser and estar can appear with these adjectives and a PP complement (cruel/mean/kind con María), dynamicity is independent from the IL and SL classification. To sum up, for Arche (2007), the distinction between ser and estar is not temporal since IL predicates are not necessarily permanent properties. This is because the length of the interval an IL property extends over can be restricted in time. The temporal interpretation of predicates depends on the content of Topic Time (TT). TT is the interval the speaker refers to and for which a particular predicate is asserted to hold. Importantly, TT is sensitive to the discourse. Since estar but not ser refers to a circumstance in which an individual finds him/herself, it links the predicate to an external situation.

\section{Final remarks}

We have seen that several researchers have tried to account for ser and estar based on syntactic, semantic and pragmatic approaches. This just shows how complex it is to characterize the behavior of the two Spanish copulas. Leaving aside the controversial topic of whether the relevant distinctions are encoded in the syntax, the semantics, the pragmatics of either, the copulas or the whole predication, most of the influential proposals seem to converge on the following general picture: Predicates with ser and estar give rise to different interpretations: ser predicates are generally (but not necessarily) associated with properties that are perceived to last, to be permanent, to be inherent while estar predicates are commonly (but not always) associated with properties that are perceived as temporary, non-inherent and easy to change. Thus, most analyses agree that ser predicates are more relaxed than estar predicates in temporal terms. Importantly, ser is seen as disconnected from the discourse while estar is seen as establishing a link to the discourse. The special relation between copulas and their linking or anchoring properties is described by the authors in different ways but they all share the intuition that estar establishes a more close relation with the discourse than ser. Notice that for Arche (2007), estar but not ser associates a property to a particular context; for Schmitt and Miller (2007) estar but not ser is temporally anchored; for Maienborn (2005) estar but not ser predicates are restricted to a specific topic (discourse); for Clements (1988), estar presupposes a connection to another situation (+Nexus) while ser does not (-Nexus), for Clements (2005), estar but not ser is aspectually marked.

Another remark that can be safely derived from the above review is that most authors agree that it is not correct to explain the uses of ser and estar based on traditional notions of temporary/ permanent, essential/non-essential properties. They seem to acknowledge that dichotomies like these are effective for explaining part of the data but in general propose that temporal associations derive from properties that do not necessarily relate to ser and estar and therefore cannot be considered the source of the explanation.

What exactly is the source of the difference between ser and estar is far from settled.According to Kratzer's (1995) and Diesing's (1992) proposals, in which ser and estar are assumed to be the lexical exponents of IL/SL predicates, the source of the difference is the presence/absence of a spatiotemporal argument. For Arche (2007), whose analysis also views ser and estar as the lexical exponents of the IL/SL distinction, ser and estar do not differ with respect to the spatiotemporal arguments they project (since both project spatiotemporal arguments) but rather on their lexical semantics: the linking nature of estar to a specific context is lexically encoded. For Maienborn $(2003,2005)$ the difference between ser and estar is only pragmatic while ser and estar have identical semantics. For Schmitt (1992, 1996, 2005) and Luján (I98I), the difference lies in the aspectual properties of the predicates involving ser and estar. For Clements (2005) it is essential to consider not only the semantics of the copulas, the adjectives and subject referents but also the discoursepragmatic dimension that may only be observable in the actual use of ser and estar by native speakers. Future research will need to focus on the pragmatic and discursive properties involved in actual speech in order to provide insights into the complex and seemingly chaotic nature and distribution of the Spanish copulas. 


\section{REFERENCES}

Alameda, J. R. \& Cuetos, F. (1995). Diccionario de frecuencias de las unidades lingüísticas del castellano. Oviedo, España: Universidad de Oviedo.

Arche, M.J. (2007). Individuals in time; tense, aspect and the individual/stage distinction.Amsterdam: Benjamins.

Bello,A. (I95I). Gramática de la lengua Castellana. Venezuela: Ministerio de Educación.

Camacho, J. (1997). La distinción aspectual entre ser y estar. In A. Mendikoetxea \& M. UribeEtxebarria (Eds.), Theoretical Issues at the morphology-syntax interface (pp. 93-I00). Bizkaia: Universidad del País Vasco.

Carlson, G. (1977). Reference to kinds in English. Umass Amherst: University of Massachussetts.

Clements, J. C. (1988). The semantics and pragmatics of the Spanish <Copula+Adjective> construction. Linguistics, 26, 779-822.

Clements, J. C. (2005). 'Ser' and 'estar' in the predicate adjective construction. In J. C. Clements \& J. Yoon (Eds.), Functional approaches to Spanish syntax: Lexical semantics, discourse, and transitivity (Pp. 161-202). London: Palgrave-Macmillan.

Delbecque, N. ( 1997). The Spanish copulas ser and estar. In M.Verspoor, K. D. Lee \& E. Sweetser (Eds.), Lexical and syntactical constructions and the construction of meaning (pp. 247-270). Amsterdam: Benjamins.

Diesing, M. (1990). Verb movement and the subject position in Yiddish. Natural Language and Linguistic Theory, 8(I), 4I-79.

Diesing, M. (1992). Indefinites. Cambridge: MA, MIT Press.

Fernández-Leborans, M. J. (1999). La predicación: Las oraciones copulativas. In I. Bosque \& V. Demonte (Eds.), Gramática Descriptiva de la Lengua Española (pp. 2357-2460). Madrid: Espasa.

Geeslin, K. \& Guijarro-Fuentes, P. (2006).The second language acquisition of variable structures in Spanish by Portuguese speakers. Language Learning, 56(I), 53- 107.

Gili Gaya, S. (1955). Curso superior de sintaxis española. Barcelona: Spes.

Guijarro-Fuentes, P. \& Geeslin, K. (2008). Language acquisition, language variation and copula choice in Spanish. Bilingualism: Language and Cognition, I I (3), 273-387.

Heim, I. (1982). The semantics of definite and indefinite noun phrases. Unpublished doctoral dissertation, University of Massachusetts, Amherst. USA.

Kratzer, A. (1989). Stage and individual level predicates. Papers on quantification. NSF Grant Report, Linguistics Department, University of Massachusetts, Amherst. USA.

Kratzer, A. (1995). Stage-Level and Individual-Level Predicates. In G. Carlson \& F. Pelletier (Eds.), The Generic Book (pp. I25- I75). Chicago, University of Chicago Press.

Leonetti, M. (1994). Ser y estar: Estado de la cuestión. Barataria, I, I 82-205.

Luján, M. (198I). The Spanish copulas as aspectual indicators. Lingua, 54, I65-210.

Maienborn, C. (2003).Against a Davidsonian analysis of copula sentences. NELS 33 Proceedings, GLSA, I67-I86.

Maienborn, C. (2005). A discourse-based account of Spanish ser/estar. Linguistics, 43(I), I55180. 
Manninen, S. (200I). A minimalist analysis of stage level and individual level predicates. Lund Working Papers in Linguistics I [online]. Retrieved from: http://www.sol.lu.se/engelska/ wp.html?expand_menu= 16

Marín-Gálvez, R. (200I). El componente aspectual de la predicación. Tesis doctoral, Universidad Autónoma de Barcelona. España.

Partee, B. ( 1977). John is easy to please. In A. Zampolli (Ed.), Linguistic structures processing (pp. 28I-3I2). Amsterdam: North-Holland Publishing Co.

Porroche, M. (1990). Aspectos de la atribución en español. Zaragoza: Pórtico.

Querido, A. (1976). The semantics of copulative constructions in Portuguese. In M. Luján \& F. Hensey (Eds.), Current studies in Romance linguistics (pp. 343-366). Washington D.C.: Georgetown University Press.

Roby, D. (2007). Aspect and the categorization of states: The case of ser and estar in Spanish. Unpublished doctoral dissertation, University of Texas of Austin. USA.

Schmitt, C. (1992). Ser and estar:A matter of aspect. NELS 22 Proceedings, GLSA, 4I I-426.

Schmitt, C. (1996). Aspect and the syntax of noun phrases. Unpublished doctoral dissertation, University of Maryland. USA.

Schmitt, C. (2005). Semi-copulas: Event and aspectual composition. In P. Kempchinsky \& R. Slabakova (Eds.), Syntax, semantics and the acquisition of aspect (pp. I2I-I45). Springer: Kluwer.

Schmitt, C. \& Miller, K. (2007). Making discourse-dependent decisions:The case of the copulas ser and estar in Spanish. Lingua, I I 7 (I I), 1907-1929.

Smith, C. (1997). The parameter of aspect. Boston: Kluwer.

Vañó-Cerdá,A. ( 1982). Ser y estar + adjetivo. Un estudio sincrónico y diacrónico. Tübingen: Gunter Narr Verlag.

Vendler, Z. (1967). Linguistics in Philosophy. Cornell University Press: Ithaca.

Verkuyl, H. (1989). Aspectual classes and aspectual composition. Linguistics and Philosophy, I2, 39-94. 